\title{
Predominant trait inheritance in wheat with multivariate approach
}

\author{
Rita Carolina de Melo $^{1^{*}}$ Marcelo de Carli Toigo ${ }^{2}$ Sergio Dias Lannes ${ }^{2}$ Nicole Trevisani ${ }^{1}$ \\ Thayse Cristine Vieira Pereira ${ }^{1}$ Sibila Grigolo ${ }^{1}$ Altamir Frederico Guidolin $^{1}$ \\ Jefferson Luís Meirelles Coimbra ${ }^{1}$
}

${ }^{1}$ Instituto de Melhoramento e Genética Molecular (IMEGEM), Universidade do Estado de Santa Catarina (UDESC), 88520-000, Lages, SC, Brasil. E-mail: rita carol mel@hotmail.com. "Corresponding author.

${ }^{2}$ Fundação Estadual de Pesquisa Agropecuária (FEPAGRO), Centro de Pesquisa da Região Nordeste, Vacaria, RS, Brasil.

\begin{abstract}
The objective of this study was to analize the inheritance of characters in wheat using multivariate analysis of variance. Sixteen genetic constitutions were evaluated between commercial cultivars and progenies $F_{1}$ and $F_{2}$. Treatments were arranged in completely randomized blocks, with three replicates. Five characters were evaluated. Multivariate analysis of variance and multivariate contrasts were then performed to test the hypotheses. The significant differences, obtained for comparison between parents and progenies $F_{p}$, may be evidence of heterosis occurrence. However, only comparisons between progenies P1_P3 (F $\left.F_{1}\right)$ vs. P1_P3 ( $\left.F_{2}\right)$ and P4_P2 (F) vs. P4_P2 (F) showed significant differences. Multivariate analysis of variance revealed that inheritance of the characters studied is predominantly of the additive type. It is possible that, this occurred due to the degree of relationship between parents who reunited identical alleles at the same locus, by ancestry, as a result of inbreeding effects. The knowledge of additive inheritance may represent a faster incorporation of resistance or quality characteristics in new cultivars.
\end{abstract}

Key words: Triticum aestivum, multivariate contrasts, additivity, inbreeding.

Herança predominante de caracteres em trigo com enfoque multivariado

RESUMO: $O$ objetivo deste trabalho foi estudar a herança de caracteres em trigo utilizando análise de variância multivariada. Foram avaliadas dezesseis constituições genéticas, entre cultivares comerciais e progênies $F_{1}$ e $F_{2}$. Os tratamentos foram dispostos em blocos completos casualizados, com três repetições. Cinco caracteres foram mensurados. Para testar as hipóteses foi realizada análise de variância multivariada, e posteriormente contrastes multivariados. As diferenças significativas obtidas para as comparações entre os genitores e as progênies $F_{1}$, podem ser indícios da ocorrência de heterose. No entanto, somente as comparações entre as progênies $P 1$ P3 ( $\left.F_{1}\right)$ vs. P1_P3 ( $\left.F_{2}\right)$ e P4_P2 $\left(F_{2}\right)$ vs. P4_P2 $\left(F_{2}\right)$ apresentaram diferenças significativas. A análise de variância multivariada revelou que a herança dos caracteres estudados é predominantemente do tipo aditiva. Isto ocorreu, possivelmente pelo grau de parentesco entre os genitores que reuniram alelos identicos no mesmo loco por ascendência, como resultado dos efeitos da endogamia. O conhecimento da herança aditiva pode representar a incorporação mais rápida de resistência ou de características de qualidade em novas cultivares.

Palavras-chave: Triticum aestivum, contrastes multivariados, aditividade, endogamia.

\section{INTRODUCTION}

The study of genetic inheritance of characters from directed crossings substantially contributes to understand the availability of genetic variability and gains with selection. The inheritance of a particular trait may be predominantly of the additive type or dominance (FEHR, 1987). Quantitatively, heterosis is measured by the difference between the value obtained in generation $F_{1}$ and the mean value of the parents, being maximum in generation $F_{1}$.
In diploid species, heterozygosis is expected to be reduced to half every self-fertilization generation due to endogamy (WRIGHT, 1950).

Making crossings between contrasting parents is necessary to study the inheritance of a character. In conducting a wheat breeding program by directed hybridization, establishing which parents should be crossed is one of the most important points because there is a large number of genotypes available. Whenever possible, other important traits should be considered while choosing the parents in a given 
cross, because they are essential for the commercial acceptance of a new cultivar (BENIN et al., 2009).

The information obtained from experiments can be enriched when analyzed in a multivariate model, since selection of genotypes should not be based on only one character (DAWSON et al., 2012; YEATER et al., 2015). Multivariate analysis of variance can identify the existing (co) variation between the response variables (HAIR et al., 2007). The possibility of clarifying both relationship and effect of each study variable may be of fundamental importance in the area of biological sciences (CASTRO et al., 2013; HUANG et al., 2015; MOUSAVIZADEH et al., 2015; SUSO \& RÍO, 2015). For example, multivariate analysis in genetic improvement may facilitate the classification and identification of superior genetic constitutions (COIMBRA et al., 2007; SCHMIT et al., 2016), as well as help understand the relationship between the characters evaluated thus allowing to understand the type of allele interaction involved in inheritance (BERTAN et al., 2009; SIAHBIDI et al., 2013). Therefore, the objective of this research was to analize the inheritance of characters of agronomic interest in wheat using a multivariate approach.

\section{MATERIAL AND METHODS}

The study was conducted during the winter crop in 2014, at the experimental field, which is located in the Research Center of the State Foundation for Agricultural Research (FEPAGRO), in the city of Vacaria (RS). The region is located in latitude $28^{\circ} 27^{\prime} \mathrm{S}$ and longitude $50^{\circ} 57^{\prime} \mathrm{W}$ (height: $950 \mathrm{~m})$. The soil is classified as typical Aluminoferric brunolatosol. According to the Koeppen international classification, the climate of the region is humid and subtropical, with mild summers.

Genetic constitutions (16) were evaluated: i) commercial cultivars (4) ('BRS 331', 'Marfim', 'CD124' e 'BRS Parrudo'); ii) progenies $\mathrm{F}_{1}$ (6), obtained by artificial crosses between cultivars forming a complete diallel, without the reciprocal ones; iii) progenies in generation $F_{2}(6)$, which were obtained by self-fertilization of progenies $\mathrm{F}_{1}$. The parents (P1: 'BRS 331'; P2: 'Marfim'; P3: 'CD124'; e P4: 'BRS Parrudo') were selected for hybridization due to their contrasting characteristics and agronomic performances (Table 1). Treatments were arranged in completely randomized blocks with three replicates. The experimental plots consisted of two 0.2-m spaced 3-m length lines, with $0.1-\mathrm{m}$ spacing between plants in the line.
Five characters were measured: (1) days from emergence to silking (DES); (2) plant height ( $\mathrm{PH}$; in $\mathrm{cm})$, measure from the soil to the top of the spike, without considering the awns; (3) peduncle length $(\mathrm{PL}$, in $\mathrm{cm})$, distance from the last internode to the base of the spike of the main stem; (4) number of spikes per plant (SPP), counting of spikes that formed grains; and (5) grain mass per plant (GMP, in g). Averages for each character were obtained from all plants of the experimental unit.

The hypotheses on the genetic constitutions were tested by the multivariate analysis of variance (MANOVA). This analysis was obtained by means of the GLM (General Linear Model) procedure of the statistical SAS (SAS Institute, 2009) software. Interpretation of the MANOVA analysis indicated the global variation in the data. However, we are interested in the comparison between treatments. For this, multivariate contrast analysis between nonorthogonal means were performed. The comparisons (structure of treatments) were performed as follows: i) average of the parents (P1, P2, P3, and P4) vs. the respective progeny $\mathrm{F}_{1}$; ii) average of progenies $\mathrm{F}_{1}$ vs. average of progenies $\mathrm{F}_{2}$. The contrasts were as follows: $\mathrm{C}_{1}$ : Mean of parents P1 and P3 vs. P1_P3 $\left(\mathrm{F}_{1}\right) ; \mathrm{C}_{2}$ : Mean of parents P2 and P3 vs. P2_P3 $\left(\bar{F}_{1}\right)$; $\mathrm{C}_{3}$ : Mean of parents P2 and P1 vs. P2_P1 $\left(\mathrm{F}_{1}\right) ; \mathrm{C}_{4}$ : Mean of parents P4 and P3 vs. P4_P3 $\left(\bar{F}_{1}\right) ; C_{5}$ : Mean of parents P4 and P1 vs. P4_P1 $\left(\mathrm{F}_{1}\right) ; \mathrm{C}_{6}$ : Mean of parents P4 and P2 vs. P4_P2 $\left(\mathrm{F}_{1}\right) ; \mathrm{C}_{7}: \mathrm{P} 1 \mathrm{P}_{-}\left(\mathrm{F}_{1}\right)$ vs. P1_P3 $\left(\mathrm{F}_{2}\right) ; \mathrm{C}_{8}: \mathrm{P} 2 \_\mathrm{P} 3\left(\mathrm{~F}_{1}\right)$ vs. P2_P3 $\left(\mathrm{F}_{2}\right) ; \mathrm{C}_{9}$ : P2_P1 $\left(\mathrm{F}_{1}\right)$ vs. P2_P1 $\left(\mathrm{F}_{2}\right) ; \mathrm{C}_{10}: \mathrm{P} 4 \mathrm{P} 3\left(\overline{\mathrm{F}}_{1}\right)$ vs. P4 P3 $\left(\overline{\mathrm{F}}_{2}\right)$; $\mathrm{C}_{11}$ : P4_P1 $\left(\mathrm{F}_{1}\right)$ vs. P4_P1 $\left(\mathrm{F}_{2}\right) ; \mathrm{C}_{12}:$ P4_P2 $\left(\mathrm{F}_{1}\right)$ vs. P4_P2 (F $)$.

To differentiate between treatments, the canonical coefficients for each contrast were analyzed for the response variables with greater canonical weight. The standardized canonical coefficients (SCC) were interpreted as follows: $i$ ) positive values indicated effect of separation between treatments, and characters with higher SCC values showed a greater weight in differentiation; ii) negative values can be interpreted in a similar manner, but with direction contrary to the effect, so that negative values reduced the effect of the response variable under consideration (HAIR et al., 2007).

\section{RESULTS AND DISCUSSION}

Multivariate analysis of variance showed a significant difference for all factors evaluated, showing that populations present genetic variability for the set of characters that were simultaneously 
Table 1 - Main characteristics of wheat parents involved in hybridizations. UDESC-IMEGEM, Lages SC, Brazil.

\begin{tabular}{|c|c|c|c|c|}
\hline Characteristics & 'BRS 331' & 'Marfim' & 'CD 124' & 'BRS Parrudo' \\
\hline Cycle (days) ${ }^{(1)}$ & 125 & 130 & 130 & 135 \\
\hline Height $(\mathrm{cm})$ & 80 (short) & 80 (short) & 78 (short) & 85 (middle) \\
\hline Productivity $\left(\mathrm{kg} \mathrm{ha}^{-1}\right)$ & 4181 & 3225 & 4136 & 4964 \\
\hline
\end{tabular}

${ }^{(1)}$ Number of days from emergence to maturity.

evaluated (Table 2). The presence of genetic variability is determinant for the continuity of studies on inheritance. However, notably, understanding of character inheritance seems to be restricted to univariate analyzes (BERTAN et al., 2009; VALENTINI et al., 2011; CARPENTIERI-PIPOLO et al., 2014). Most characters of agronomic interest are ruled by numerous pairs of alleles, so that the study of a single character is already very complex. However, the great advantage of applying multivariate analysis is in considering the covariance between variables. As the expression of any character is influenced by numerous other characters, multivariate analysis of variance can contribute to the knowledge of the inheritance type prevailing in wheat progenies.

Contrast $\mathrm{C}_{1}$ showed a significant difference between means of parents vs. $\mathrm{F}_{1}$. The characters that most contributed to the differentiation in this comparison were as follows: DES (0.18), PL (0.84) and GMP (0.87). Thus, the heterosis phenomenon should be considered, as well as the predominance of allelic interactions of the non-additive type. Possibly, artificial hybridization resulted in the action and interaction between favorable dominant alleles expressing a greater hybrid vigor. BERTAN et al. (2009) studied traits in wheat and reported different heterosis levels in all characters analyzed as a function of specific effects in each cross.

Significant differences were observed between genetic constitutions $\mathrm{P} 2$ and $\mathrm{P} 1$ vs. P2 P1 $\left(\mathrm{F}_{1}\right)$ (contrast $\mathrm{C}_{3}$ ). Combination between parents allowed the assembly of different alleles and provided the appearance of heterozygous loci in generation $\mathrm{F}_{1}$. The characters positively contributed to differentiate the treatments, except SPP $(-1.86)$, which presented the lowest canonical weight, i.e., the lowest relative contribution to distinguish between mean vectors.

The multivariate contrasts between the parental average and the respective $F_{1}$ progeny revealed the presence of significant differences, except contrast $\mathrm{C}_{2}\left(\mathrm{P} 2\right.$ and $\mathrm{P} 3$ vs. P2 P3 $\left(\mathrm{F}_{1}\right)$ ). This result suggested that a higher degree of relationship between the parents mentioned above may exist, bringing together alleles identical by ancestry in the same locus (MALÉCOT, 1966). Comparison between progenies P2_P3 $\mathrm{F}_{1}$ and P2_P3 $\left(\mathrm{F}_{2}\right)\left(\mathrm{C}_{8}\right)$ also revealed no significant difference. The mean vectors for the set of characters evaluated for the genetic

Table 2 - Summary of multivariate analysis of variance by means of four statistical tests for agronomic traits days from emergence to silking (DES), plant height (PH), peduncle length (PL), number of spikes per plant (SPP) and grain mass per plant (GMP). Analysis for block and population effects. UDESC-IMEGEM, Lages SC, Brazil.

\begin{tabular}{|c|c|c|c|c|c|}
\hline Effects & Statistical tests & Values & F values & $\mathrm{DFN}^{(1)}$ & $\mathrm{DFD}^{(2)}$ \\
\hline \multirow{4}{*}{ Block } & Wilk's Lambda & $0.36^{*}$ & 4.06 & 10 & 60.0 \\
\hline & Pillai's trace & $0.80^{*}$ & 4.17 & 10 & 62.0 \\
\hline & Hotelling-Lawley & $1.36^{*}$ & 4.01 & 10 & 42.3 \\
\hline & Roy's Maximum Root & $0.81^{*}$ & 5.03 & 5 & 31.0 \\
\hline \multirow{4}{*}{ Population } & Wilk's Lambda & $0.01^{*}$ & 7.00 & 85 & 149.4 \\
\hline & Pillai's trace & $3.20^{*}$ & 3.57 & 85 & 170.0 \\
\hline & Hotelling-Lawley & $34.53^{*}$ & 11.62 & 85 & 93.7 \\
\hline & Roy's Maximum Root & $19.64^{*}$ & 39.28 & 17 & 34.0 \\
\hline
\end{tabular}

$\mathrm{H}_{0}: \mu_{1}=\mu_{2}=\ldots=\mu_{\mathrm{k}}, \mathrm{H}_{\mathrm{A}}$ : at least two $\mu$ values are different. ${ }^{(1)} \mathrm{DFN}$ : Degrees of freedom of the numerator. ${ }^{(2)} \mathrm{DFD}$ : Degrees of freedom of the denominator. ${ }^{*} \mathrm{H}_{0}$ rejected at $5 \%$ level of error probability. 
constitutions mentioned above were not significant. Thus, it can be established that most of the genome in these populations is represented by homozygous loci, which were not contrasting for the traits studied.

Another form of inbreeding that can lead to increases in the number of homozygous loci depends on the degree of relationship between the parents involved in the crossing. The higher the parentage relationship, the greater the probability that two genes present in a certain locus of this individual, are identical by ancestry, which is also known as inbreeding coefficient (MALÉCOT, 1966).

The multivariate contrasts showed that the $\mathrm{PH}$ and SPP characters were not changed in $75 \%$ of linear comparisons between means, independent of the genetic constitution evaluated (Table 3). Wide genetic variability was not observed in the characters mentioned in the study populations, possibly because there are gene blocks associated with expression of this character. The use of recurrent selection is one of the strategies recommended to break such threshold. This breeding method increases the frequency of favorable alleles in a population through selection and cross-linking cycles, explores genetic variability, and results in a greater probability of obtaining genetic gains (ALVES et al., 2015).

Only the contrasts of means $\mathrm{C}_{7}$ and $\mathrm{C}_{12}$ (between progenies $\mathrm{F}_{1} v s$. progenies $\mathrm{F}_{2}$ ) revealed significant differences. In these crossings, allele segregation significantly affected the characters through self-fertilization, mainly PL (0.82) and GMP (0.53) in contrast $\mathrm{C}_{7}$, and DES (0.06), PL (0.63), and $\operatorname{GMP}(1.43)$ in contrast $\mathrm{C}_{12}$.

Since inheritance is a genetic information, it belongs to a particular trait and a given population, significant differences were not observed in the comparisons $(67 \%)$ between progenies $\mathrm{F}_{1} v s . \mathrm{F}_{2}$. Thus, predominance of additive-type genetic inheritance occurred. One of the most important characteristics of additive-type allelic interaction is that selection can be facilitated, as an individual (or group of superior individuals) produces an offspring, which is also superior when selected (CHELAIFA et al., 2013).

This result demonstrated the advanced state of improvement of elite cultivars used as parents, which resulted from a long and continuous process of launching new cultivars. The latest achievements resulted in capitalization of most of the additive genetic inheritance available. When dominance is absent in the segregating population, genetic variance is equal for all gene frequencies (HALLAUER, 1975). In Brazil, recurrent use of genotypes with desirable characteristics and high overall combining ability directly contributes to restrict the genetic basis of wheat (BERED et al., 2000). This information was confirmed by the study conducted by SOUZA $\&$ CAIERÃO (2014). These authors reported that 547 wheat cultivars were indicated for cultivation in Brazil in the period 1922-2014, and only 11 parents were more often used to generate new cultivars, with

Table 3 - Multivariate test for contrasts and standardized canonical coefficients (SCC) for response variables: days from emergence to silking (DES), plant height (PH), peduncle length (PL), number of spikes per plant (SPP) and grain mass per plant (GMP). Wilk's U statistics. UDESC-IMEGEM, Lages SC, Brazil.

\begin{tabular}{|c|c|c|c|c|c|c|}
\hline Contrasts $^{(1)}$ & $\mathrm{U}$ & DES & $\mathrm{PH}$ & PL & SPP & GMP \\
\hline $\mathrm{C}_{1}$ & $0.409^{*}$ & 0.18 & -0.31 & 0.84 & -1.08 & 0.87 \\
\hline $\mathrm{C}_{2}$ & 0.905 & 0.53 & -0.37 & 0.25 & -1.92 & 1.91 \\
\hline $\mathrm{C}_{3}$ & $0.620^{*}$ & 0.23 & 0.01 & 0.47 & -1.86 & 1.41 \\
\hline $\mathrm{C}_{4}$ & $0.622^{*}$ & 0.34 & -0.17 & 0.48 & -1.84 & 1.44 \\
\hline $\mathrm{C}_{5}$ & $0.469^{*}$ & 0.59 & -0.42 & 0.47 & -1.32 & 1.38 \\
\hline $\mathrm{C}_{6}$ & $0.470^{*}$ & 0.45 & -0.23 & 0.36 & -1.97 & 1.81 \\
\hline $\mathrm{C}_{7}$ & $0.554^{*}$ & -0.12 & -0.15 & 0.82 & -0.88 & 0.53 \\
\hline $\mathrm{C}_{8}$ & 0.905 & 0.38 & -0.16 & 0.34 & -2.09 & 1.79 \\
\hline $\mathrm{C}_{9}$ & 0.751 & 0.42 & -0.09 & -0.33 & 1.02 & -0.65 \\
\hline $\mathrm{C}_{10}$ & 0.845 & 0.18 & -0.08 & 0.09 & 1.52 & -0.95 \\
\hline $\mathrm{C}_{11}$ & 0.914 & 0.31 & -0.76 & 0.13 & -1.30 & 1.68 \\
\hline $\mathrm{C}_{12}$ & $0.586^{*}$ & 0.06 & -0.25 & 0.63 & -1.73 & 1.43 \\
\hline
\end{tabular}

\footnotetext{
${ }^{(1)} \mathrm{C}_{1}$ : Mean of parents P1 and P3 vs. P1_P3 $\left(\mathrm{F}_{1}\right) . \mathrm{C}_{2}$ : Mean of parents P2 and P3 vs. P2_P3 $\left(\mathrm{F}_{1}\right)$. $\mathrm{C}_{3}$ : Mean of parents P2 and P1 vs. P2_P1 $\left(\mathrm{F}_{1}\right)$. $\mathrm{C}_{4}$ : Mean of parents P4 and P3 vs. P4_P3 $\left(\mathrm{F}_{1}\right) . \mathrm{C}_{5}$ : Mean of parents P4 and P1 vs. P4_P1 $\left(\mathrm{F}_{1}\right) . \mathrm{C}_{6}$ : Mean of parents P4 and P2 vs. P4_P2 $\left(F_{1}\right)$. C 7 : P1_P3 $\left(F_{1}\right)$ vs. P1_P3 $\left(F_{2}\right)$. C 8 : P2_P3 $\left(F_{1}\right)$ vs. P2_P3 $\left(F_{2}\right) . C_{9}:$ P2_P1 $\left(F_{1}\right)$ vs. P2_P1 $\left(F_{2}\right)$. C 10 : P4_P3 $\left(F_{1}\right)$ vs. P4_P3 $\left(F_{2}\right)$. $\mathrm{C}_{11}$ : P4_P1 $\left(\mathrm{F}_{1}\right)$ vs. P4_P1 $\left(\mathrm{F}_{2}\right) . \mathrm{C}_{12}: \mathrm{P} 4 \_\mathrm{P} 2\left(\mathrm{~F}_{1}\right)$ vs. P4_P2 $\left(\mathrm{F}_{2}\right) .{ }^{*} \mathrm{H}_{0}$ rejected at $5 \%$ level of error probability by the Wilk's Lambda test.
} 
predominance of the 'Frontana' cultivar. According to LOPES et al. (2015), there are two potential bottlenecks in wheat diversity. The first one is related to the recent origin of wheat (about 8000 years ago), assuming that there are relatively few crosses between tetraploid and diploid parents. Thus, only part of the diversity of $T$. dicoccoides and Aegilops squarosa is present in wheat. The second bottleneck is related to founding lines for local populations, where breeding programs often depend on a relatively limited number of parental lineages (elite lineages) in the development of germplasm.

On the other hand, each wheat breeding cycle requires from four to eight years until the production of genetically uniform lines, and at least three years of experimentation, to conduct comparative tests with witness varieties that are in cultivation, which corresponds to 10-12 years so that the new cultivar reaches the crops. Thus, knowledge of the predominant additive-type inheritance allows the breeder to accelerate character fixation. This may represent an increase in the production of test lineages aiming to indicate new cultivars and, above all, a greater speed in the incorporation of new resistance or quality genes in adapted cultivars.

\section{CONCLUSION}

The multivariate analysis of variance indicated that inheritance of characters in wheat is predominantly governed by the additive-type genetic variance. Knowledge of additive-type inheritance may represent a greater speed in the incorporation of new resistance or quality genes in adapted cultivars.

\section{ACKNOWLEDGMENTS}

To the Universidade do Estado de Santa Catarina (UDESC), Conselho Nacional de Desenvolvimento Científico e Tecnológico (CNPq), Coordenação de Aperfeiçoamento de Pessoal de Nível Superior (CAPES) and Fundação de Apoio à Pesquisa Científica e Tecnológica do Estado de Santa Catarina (FAPESC) for the scholarship granting and financial support fot the development of the presente research.

\section{REFERENCES}

ALVES, A.F. et al. Genetic progress and potential of common bean families obtained by recurrent selection. Crop Breeding and Applied Biotechnology, v.15, p.218-226, 2015. Available from: $<$ http://dx.doi.org/10.1590/1984-70332015v15n4a38>. Accessed: Aug. 12, 2016. doi: 10.1590/1984-70332015v15n4a38.

BENIN, G. et al. Combining ability of wheat genotypes estimated by multivariate analysis. Pesquisa Agropecuária Brasileira, v.44, n.9, p.1145-1151, 2009. Available from: <https://seer.sct.embrapa. br/index.php/pab/article/view/2479/5816>. Accessed: Aug. 20, 2016. doi: 10.1590/S0100-204X2009000900012.

BERED, F. et al. Variabilidade genética em trigo. Biotecnologia Ciência \& Desenvolvimento, n.14, p.22-25, 2000. Available from: <http://biotecnologia.com.br/revista/bio14/variabi.pdf $>$. Accessed: Sept. 01, 2016.

BERTAN, I. et al. Efeitos da heterose e endogamia em caracteres de importância agronômica em trigo. Revista Ceres, v.56, n.6, p.753-763, 2009. Available from: <http://www.redalyc.org/ articulo.oa?id=305226942008>. Accessed: Jan. 10, 2017.

CARPENTIERI-PIPOLO, V. et al. Inheritance of late flowering in natural variants of soybean cultivars under short-day conditions. Pesquisa Agropecuária Brasileira, v.49, n.10, p.796-803, 2014. Available from: <http://dx.doi.org/10.1590/S0100204X2014001000006>. Accessed: Sept. 08, 2016. doi: 10.1590/ S0100-204X2014001000006.

CASTRO, A.F.N.M. et al. Multivariate analysis for the selection of eucalyptus clones destined for charcoal production. Pesquisa Agropecuária Brasileira, v.48, n.6, p.627-635, 2013. Available from: <http://dx.doi.org/10.1590/S0100204X2013000600008>. Accessed: Aug. 12, 2016. doi: 10.1590/ S0100-204X2013000600008.

CHELAIFA, H. et al. Prevalence of gene expression additivity in genetically stable wheat allohexaploids. New Phytologist, v.197, p.730-736, 2013. Available from: <http://dx.doi. org/10.1111/nph.12108>. Accessed: Aug. 20, 2016. doi: 10.1111/nph. 12108 .

COIMBRA, J.L.M. et al. Técnicas multivariadas aplicadas ao estudo da fauna do solo: contrastes multivariados e análise canônica discriminante. Revista Ceres, v.54, n.313, p.271277, 2007. Available from: <http://www.redalyc.org/articulo. oa?id=305226813006>. Accessed: Sept. 01, 2016.

DAWSON, J.C. et al. Multi-trait evolution of farmer varieties of bread wheat after cultivation in contrasting organic farming systems in Europe. Genetica, v.140, p.1-17, 2012. Available from: $<$ http://dx.doi.org/10.1007/s10709-012-9646-9>. Accessed: Aug. 10, 2016. doi: 10.1007/s10709-012-9646-9.

FEHR, W.R. Principles of cultivars development. New York: Macmillan, 1987. 536p.

HAIR, J.F.J. et al. Análise multivariada de dados. 6.ed. São Paulo: Bookmam, 2007. 593p.

HALLAUER, A.R. Relation of gene action and type of testers in maize breeding programs. Annual Corn Sorghum Conference, v.30, p.150-159, 1975.

HUANG, M. et al. Diallel analysis of combining ability and heterosis for yield and yield components in rice by using positive loci. Euphytica, v.205, p.37-50, 2015. Available from: <http:// dx.doi.org/10.1007/s10681-015-1381-8>. Accessed: Sept. 10, 2016. doi: 10.1007/s10681-015-1381-8.

LOPES, M.S. et al. Exploiting genetic diversity from landraces in wheat breading for adaptation to climate change. Journal of Experimental Botany, v.66, n.12, p.3477-3486, 2015. Available from: <http://dx.doi.org/10.1093/jxb/erv122>. Accessed: Sept. 10, 2016. doi: 10.1093/jxb/erv122. 
MALÉCOT, G. Probabilités et hérédité. Paris: Presses, Universitaires de France 1966. 356p.

MOUSAVIZADEH, S.J. et al. Multivariate analysis of edible Asparagus species in Iran by morphological characters. Euphytica, v.206, p.445-457, 2015. Available from: $<$ http://dx.doi. org/10.1007/s10681-015-1508-y>. Accessed: Sept. 10, 2016. doi: 10.1007/s10681-015-1508-y.

SAS Institute. SAS/STAT: user's guide version 9.2. Cary, 2009. 60p

SCHMIT, R. et al. Application of multivariate techniques in the evaluation of pure lines of beans. Ciência Rural, v.46, n.9, p.15351541, 2016. Available from: <http://dx.doi.org/10.1590/01038478cr20140329>. Accessed: Sept. 02, 2016. doi: 10.1590/0103$8478 \mathrm{cr} 20140329$.

SIAHBIDI, M.M.P. et al. Evaluation of genetic diversity and interrelationships of agromorphological characters in durum wheat (Triticum durum desf.) lines using multivariate analysis. International Journal of Agriculture, v.3, n.1, p.184-194, 2013. Available from: <http://search.proquest. com/openview/d30435836651180c5d0b4b792d1207d3/1?pqorigsite $=$ gscholar\&cbl=1596380> . Accessed: Jan. 10, 2017.
SOUZA, C.N.A.; CAIERÃO, E. Cultivares de trigo indicadas para cultivo no Brasil e instituições criadoras 1922 a 2014. 2.ed. Brasília: Embrapa, 2014. 200p.

SUSO, M.J.; RÍO, R. del. A crop-pollinator inter-play approach to assessing seed production patterns in faba bean under two pollination environments. Euphytica, v.201, p.231-251, 2015. Available from: <http://dx.doi.org/10.1007/s10681-014-1200-7>. Accessed: Sept. 03, 2016. doi: 10.1007/s10681-014-1200-7.

VALENTINI, G. et al. Herança da resistência em feijoeiro à murcha causada por Curtobacterium flaccumfaciens pv. flaccumfaciens. Pesquisa Agropecuária Brasileira, v.46, n.9, p.1045-1052, 2011. Available from: $<$ http://dx.doi.org/10.1590/S0100-204X2011000900011>. Accessed: Aug. 28, 2016. doi: 10.1590/S0100-204X2011000900011.

WRIGHT, S. The genetical structure of populations. Annals of Eugenics, v.15, p.323-354, 1950. Available from: <http:// onlinelibrary.wiley.com/doi/10.1111/j.1469-1809.1949.tb02451.x/ pdf>. Accessed: Apr. 24, 2017.

YEATER, K.M. et al. Multivariate analysis: greater insights into complex systems. Agronomy Journal, v.107, n.2, p.799-810, 2015. Available from: <http://dx.doi.org/10.2134/agronj14.0017>. Accessed: Sept. 02, 2016. doi: 10.2134/agronj14.0017. 